
e-mail: grineva_olga@ukr.net.

\title{
Психологічні аспекти дослідження феномена проектування життєвого шляху особистості
}

Анотація. У статті представлено результати дослідження проблеми проектування життєвого шляху особистості. Проаналізовано основні підходи вчених до вивчення змісту, структури, механізмів проектування життєвого шляху особистості в сучасному суспільстві.

Ключові слова: проектування життевого шляху, особистість, смисл життя, життєві цілі, життєві плани, самовизначення, самоздійснення, сучасне суспільство.

Постановка проблеми. На сучасному етапі становлення Української держави, в умовах суспільно-економічної кризи та значної кількості трагічних подій, які глибоко переживаються кожним громадянином, несприятливий вплив соціальних факторів зумовлює негативні зміни на рівні свідомості окремої особистості. Зокрема, до таких змін належить становлення ряду стійких негативних психічних утворень особистісного розвитку сучасних українців (страхів, тривожності, невпевненості у своєму майбутньому, пригніченості, розгубленості та ін.). За таких умов генерування людиною життєвих цілей, планів і стратегій самореалізації у різних модусах власного існування надзвичайно ускладнюється. Водночас глибинні переживання сучасною особистістю кризових подій у країні, сучасного надзвичайно складного етапу національно-культурного відродження української нації й власної ролі як співавтора історії власного народу обумовлює переоцінку нею власних цінностей, переосмислення сенсу власного існування й активізації особистісної свободи й відповідальності у процесі побудови авторського проекту власного життєвого шляху. Таким чином, складність та неоднозначність впливу соціальних факторів на процес проектування особистістю свого житєвого шляху в умовах українського сьогодення обумовлюють високу актуальність і суспільну значущість вивчення цього феномена.

Аналіз останніх публікацій. Вивченню різних аспектів проектування життєвого шляху людини присвячено ряд спеціаль- них психологічних досліджень. Так, вперше дослідження життя людини як іiї індивідуальної історії висвітлено ще у роботах Ш. Бюлер і Ф. Массарік. Рушійною силою особистісного зростання й проходження людиною основних стадій розвитку є процес неперервного самовизначення й самоздійснення. Водночас самоздійснення $€ \mathrm{i}$ основною метою життєвого шляху людини [17]. В основі самоздійснення особистості, згідно з вченими, лежать іiї базові тенденції [18]. Тенденція до невпорядкованості психічного розвитку людини, внутрішньоособистісних протиріч зумовлює зростання у неї напруги, виникнення неврозів. Натомість самовизначення індивідуума сприяє упорядкуванню його внутрішнього світу й зниження напруги у ньому [17]. Слідом за Ш. Бюлер К.О. Абульханова-Славська, В.А. Петровський, С.Л. Рубінштейн та ін. підкреслили виключне значення проектування людиною свого життєвого шляху як умови іiі особистісного зростання та нерозривний взаємозв'язок зазначеного психічного утворення з іншими особистісними утвореннями, зокрема - життєвим вибором і самовизначенням (Б. Г. Анан'єв, С. Л. Рубінштейн), життєвим світом і життєконструюванням (К.О. АбульхановаСлавська, В.Ю. Василюк, А.В. Петровський, Т.М. Титаренко), життєвими планами і стратегіями (А. М. Ляхова, Т.М. Рєзнік і Ю. М. Резнік, Е. Фромм) та ін.

Тому метою цієї статті $є$ дослідження психологічних аспектів вивчення проектування життєвого шляху особистості у роботах радянських, сучасних українських 
i російських вчених, а також поглядів дослідників на проблему взаємозв' язку цього феномена $з$ іншими психічними утвореннями.

Виклад основного матеріалу. Згідно 3 С. Л. Рубінштейном, проходження кожного «вузлового моменту» життя індивідуума відбувається в умовах як внутрішньої, так і зовнішньої детермінації. Однак способи реагування на різні стимули визначає сам суб'єкт. Здатність особистості робити власний вибір і являє собою самовизначення. Основою самовизначення $є$ самодетермінація, оскільки «...особистість не лише знаходиться у певному відношенні до світу, але і сама визначає це своє ставлення, у чому і полягає свідоме самовизначення людини» [14, с. 243]. Самодетермінація, самовизначення особистості зумовлюють становлення у неї суб'єктності, здатності до усвідомленої побудови, проектування власного життя, продуктивної самотрансценденції відносно світу й інших людей [3].

Життєвий світ як спосіб конструювання особистістю життєвого шляху досліджувався у роботах К.О. Абульханової-Славської [1], В.Ю. Василюка [5; 6], А.В. Петровського [11], Т.М. Титаренко [15] та ін. В основу досліджень життєвого світу авторів покладено наявні у зарубіжній i радянській психології розробки часового (життєвий час) й ціннісно-смислового (життєвий простір) аспектів життєвого шляху особистості. Становлення життєвого простору індивідуума зумовлює його здатність робити життєві вибори або приймати життєві рішення.

А.В. Петровський відзначив наявність у житті людини внутрішньоіндивідного, інтеріндивідного і метаіндивідного життевих просторів. На думку вченого, найбільш широким $є$ метаіндивідний простір, який виходить за просторово-часові межі життя людини і являє собою систему трансценденційних впливів суб'єкта на особистісно-духовне зростання інших людей [11]. Подальший розвиток досліджень метаіндивідного простору А.В. Петровського у часовому аспекті представлений у ро- ботах Т. М. Титаренко і С.Д. Максименка. Дослідники підкреслили, що життя людини триває, доки живі ï нащадки, тривають iii справи, а спогади про особистість та їі життєвий шлях впливають на життя інших людей $[10 ; 15]$.

К.О. Абульханова-Славська у життєвому просторі особистості виділила дві складові: «життя для себе» $\mathrm{i}$ «життя для інших». Успішність дотримання індивідуумом оптимального балансу між структурними компонентами життєвого простору на основі власних ціннісно-смислових орієнтацій зумовлює становлення у нього своєчасності - уявлень про оптимальний час здійснення різних видів діяльності. Оцінка своєчасності є основою прийняття рішень про реалізацію чи відмову від різних життєвих завдань [1].

У основу типології життєвих світів особистості Ф. Ю. Василюка покладено феномен потреби. У процесі особистісного зростання людини відбувається збільшення кількості їі потреб, що зумовлює ускладнення iї внутрішнього світу. Підвищення якісної складності потреб людини та пролонгованості у часі їх реалізації відображає підвищення суб' єктивного сприймання важкості їі зовнішнього світу. Тому найвищим рівнем життєвого світу особистості $€$ складний всередині і важкий назовні. Становлення такого життєвого світу сприяє зростанню особистісної інтегрованості й спрямоване на реалізацію не іï окремих потреб, а життєвого задуму у цілому. Чіткість й розробленість життєвого задуму людини обумовлює успішність іï життєвих виборів, оскільки «...вибір буде тим гірший, чим менш ясно крізь строкатість поверхових зв'язків суб'єкт може побачити відмінності протилежних смислів і чим більше вибір грунтується на ситуативних зручностях чи обмеженнях. Суб'єкт при цьому всьому дедалі більше виявляється «загіпнотизованим», полоненим ситуативною поверховістю життя» [6, с. 289-290].

Особливості життєвого вибору в умовах боротьби мотивів розглядав і В.А. Роменець. У його концепції життєвого вчинку основою життєвого вибору є прийняття 
людиною життєвого рішення як процес боротьби мотивів. Безперспективний для реалізації життєвих планів особистості, але емоційно привабливий мотив вчений назвав «спокусою». Прийняття життєвого рішення - це процес протиріччя між перспективними мотивами, які відображають екзистенційні потреби особистості і сприятимуть їх задоволенню у майбутньому 3 одного боку, і мотивами, що відображають потреби нищого порядку (як правило, гедонічні), актуальні у теперішньому, - 3 другого. Глибинне осмислення життєвого шляху, власні переконання як основа життєвих цілей зумовлюють можливість особистості протидіяти спокусі. Прийняття життєвого рішення на користь екзистенційних мотивів $є$ складним процесом, оскільки: «Людина хоче визначити себе, надати сенсу своєму життю, а це означає обмежити себе, адже сенс є лише тонкою лінією на безмежному полі життя. Спокуса тому і звернена до людської універсальності, прагне іiі розкрити, втопити у всеблаженстві буття...» [13, с. 359-360].

К.О. Абульханова і Т.Н. Березіна [2], Т. М. Титаренко [15] також підкреслили, що основою життєвої спрямованості на задоволення екзистенційних потреб особистості $€$ глибинне осмислення нею власної індивідуальності й свого місця у світі, оскільки «інтенціональність базується на смисловій матриці...» [15, с. 314]. Смисложиттєві когніції як передумова життєвої спрямованості зумовлюють здійснення людиною життєвих виборів на основі життєвих цілей, а не сподівань чи відчаю. Життєві цілі включають переживання життєвої потреби, власної відповідальності за їі задоволення і готовність протидіяти життєвим труднощам [2]. Інтернальність локусу контролю особистості як необхідну умову реалізації іiі життєвих цілей підкреслила і Т. М. Титаренко. Згідно з вченою, «...реальна, конкретна особистість створює свій унікальний життєвий шлях через оволодіння обставинами, контроль над собою та зусилля аби ствердити свою необхідність у конкретно-історичному світі» [15, с. 94]. Способом життєконструювання особистості є побудова життєвого світу, важливою складовою якого є життєвий простір. Найвищим рівнем конструювання життєвого шляху людини є суб'єктний життєвий простір. Він достатньо відкритий через життєву спрямованість «...на інших, їхні інтереси, очікування, потреби» $[15$, с. 70$]$. У центрі такого простору «...опиняється активний суб'єкт, що приймає самостійні рішення, бере на себе відповідальність за все, що відбувається, прагне перетворити самого себе відповідно до значущих цінностей» [15, с. 70]. Механізмом життєздійснення людини є життєвий вибір, тобто «...зважене, свідоме рішення, що визначає на майбутнє основну стратегію життєздійснення. Це довільний і свобідний акт, що на певний час, на певному етапі життєвого шляху формує напрям подальшого розвитку» $[15$, с. 323$]$.

Здійснений аналіз літературних джерел дає можливість констатувати, що конструювання особистістю життєвого світу у роботах сучасних дослідників розглядається як процес формування ціннісно-смислової основи життєвого проекту та її подальшої продуктивної реалізації у міжособистісній взаємодії. Становлення обох зазначених аспектів побудови життєвого шляху людини дослідники пов'язують 3 феноменом вибору. У роботах дослідників представлені різні інтерпретації вибору: прийняття рішення у відносно невизначеній ситуації (О.І. Ларичев, С.Б. Ребрік); вибір однієї можливості з ряду усвідомлених (Т.В. Корнілова, І.М. Камєнєв, О.В. Степаносова; О.К. Тихомиров); життєве «завдання на вибір» (В. М. Дружинін) та ін.

Усі зазначені аспекти проблеми вибору у психологічній науці охоплює термін «самовизначення» або «особистісне самовизначення». Методологічні основи дослідження самовизначення особистості у радянській психології закладено С. Л. Рубінштейном. Самовизначення $\epsilon$ результатом інтеграції особистісної й соціальної складових життєвого світу. Згідно $з$ дослідником, «...людина не лише знаходиться у певному ставленні до світу, але й сама визначає це своє ставлення, в чому і полягає свідоме самовизначення людини» 
[10, с. 243]. «Внутрішній момент» самовизначення, за С.Л. Рубінштейном, полягає у «...вірності собі, неоднобічному підкоренні зовнішньому» $[14$, с. 382$]$.

Ціннісно-смислова основа самовизначення особистості підкреслюється у дослідженнях В. А. Бодрова і М. Р. Гінзбурга. Згідно з М.Р. Гінзбургом, самовизначення являє собою процес інтеграції особистістю просторово-часових і ціннісно-смислових орієнтирів свого життя і побудови подальшої траєкторії власного існування. Самовизначення являє собою «...змістовне конструювання людиною свого життевого поля, що містить у собі як сукупність індивідуальних життєвих смислів, так і простір реальної дії (актуальної й потенційної)» [7, с. 47]. В.А. Бодров розглядає самовизначення як результат становлення особистісно-смислових утворень, які складають «особистісний фактор». Специфіка особистісного фактору визначає зміст i особливості самовизначення i, як наслідок, становлення психічних новоутворень. Водночас самовизначення як процес відбувається шляхом пошуку смислів у різних видах діяльності, наприклад - у професійному. Результатом такого осмислення $\epsilon$ узгодження бажань, інтересів і потреб особистості з вимогами соціуму [4].

Продуктивність самоздійснення особистості обумовлюється особливостями іiі самовизначення у різних модусах життя. Самовизначення суб'єкта життєвого шляху у всій системі складних взаємозв'язків між різними узгодженими або суперечливими життєвими лініями визначає успішність, узагальненість та інтегрованість побудови ним життєвих планів й продуктивність життєздійснення або, згідно з С. Д. Максименком, за виключенням пізніх етапів життєвого шляху, коли у цілому вже можна оцінити внесок окремої особистості у прогресивний прогрес людства, еквівалентом життєздійснення є самореалізація [10]. Здійснений аналіз літературних джерел не виявив грунтовних досліджень взаємозв'язку самовизначення особистості з особливостями по-

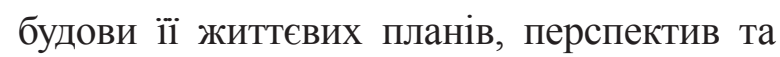
самореалізації. Однак окремо різні аспекти вивчення цих особистісних утворень представлені у сучасній психології.

Життєві плани являють собою часовий аспект життєвих цілей особистості. Це ідеальні образи міри реалізації життєвих цілей особистості на різних віхах їі життя у майбутньому. Згідно з І.С. Коном, становлення життєвих планів особистості відбувається тоді, коли усвідомлені не лише життєві цілі, але й способи та ресурси їх досягнення [8]. Таким чином, основними складовими життєвих планів є життєва стратегія (спосіб досягнення цілей життя) і життєва перспектива (оцінка ймовірності здійснення життєвих планів). За К. О. Абульхановою-Славською, життєва стратегія являє собою способи зміни особистістю оточуючої іiї дійсності відповідно до власних ціннісно-смислових орієнтацій. У процесі активізації життєвої стратегії людини постійно відбувається корекція їі активності: індивідуум поступається соціуму у другорядних життєвих ситуаціях заради досягнення пріоритетних цілей [1].

Життєві стратегії забезпечують організацію діяльності особистості відповідно до уявлень про своє майбутнє, можливості реалізації у теперішньому власних ціннісно-смислових конструктів. Так, на думку А. М. Ляхової, життєва стратегія являє собою «...форму або спосіб свідомого планування й конструювання людиною власного життя у відповідності з властивою їй системою цінностей, смислів і цілей...» [9, с. 84]. Успішність побудови життєвих стратегій особистості зумовлює ефективність ії життєдіяльності й задоволеність життям.

Оскільки основою життєвої стратегії є iii ціннісно-смислові конструкти, то особливості становлення життєвої стратегії особистості відображають специфіку їі смисложиттєвих орієнтацій та самовизначення. Важливими критеріями побудови сучасних типологій життєвих стратегій $€$ егоїстичні чи альтруїстичні смисложиттєві орієнтації, що лежать у їх основі, й суб'єктність. Так, Е. Фромм виділив дві основні життєві стратегії: «мати» (у основі стратегії - егоцентрична спрямованість, 
споживацьке ставлення до світу) й «бути» (спрямованість людини на відкриття свого дійсного буття у гармонії з іншими) [16]. Т.Є. Рєзнік і Ю.М. Рєзнік також виділили егоїстичний (життєвого благополуччя, життєвого успіху) і альтруїстичний (життєвої самореалізації) типи життєвих стратегій [12]. Осмислення індивідуумом власного буття й подальше самовизначення, конструювання на цій основі життєвих цілей, планів і стратегій зумовлюють успішність практичного втілення ідеальної моделі життєвого проекту у теперішньому, тобто самореалізації.

Висновки. Здійснений аналіз літературних джерел не виявив у фаховій літературі єдиного концептуального підходу до проектування життєвого шляху особистості. Водночас у спеціальних дослідженнях зарубіжних, вітчизняних і сучасних українських та російських психологів 3 проблеми життєвого шляху досліджено становлення усіх структурних компонентів проектування психічного розвитку особистості, що підкреслюються в інших гуманітарних науках. До таких складових належать ціннісно-смислова основа життєвого проекту (ціннісні й смисложиттеві орієнтації), побудова моделі життєвого шляху (самовизначення у різних модусах життєдіяльності), моделювання й конструювання (життєві плани й стратегіi) та ін. Однак здійснений аналіз фахової літератури не виявив у роботах вчених єдиного концептуального підходу до вивчення цього феномена. Тому перспективами подальшого дослідження проблеми проектування життєвого шляху особистості є вивчення його психологічних умов, механізмів, детермінант, закономірностей і особливостей становлення цього феномена у різні вікові періоди та ін.

\section{Список використаних джерел:}

1. Абульханова-Славская К.А. Стратегия жизни / К.А. Абульханова-Славская. - М. : Мысль, 1991. - 299 с.

2. Абульханова К.А. Время личности и время жизни / К. А. Абульханова, Т.Н. Березина. - СПб. : Алетейя, 2001. - 304 с.

3. Абульханова К.А. Философско-психологическая концепция С. Л. Рубинштейна : к 100летию со дня рождения / К. А. Абульханова, А.В. Брушлинский. - М. : Наука, 1989. $-248 \mathrm{c}$.

4. Бодров В. А. Психология профессиональной пригодности / В. А. Бодров. - М. : ПЕР СЭ, 2001. - $511 \mathrm{c}$.

5. Василюк Ф.Е. Психология переживания. Анализ преодоления критических ситуаций / Ф.Е. Василюк. - М. : Издательство Московского университета, 1984. — 200 с.

6. Василюк Ф.Е. Психотехника выбора // Психология с человеческим лицом: Гуманистическая перспектива в постсоветской психологии / [Под ред. Д. А. Леонтьева, В. Г. Щур]. - М. : Смысл, 1997. - С. 284-314.

7. Гинзбург М.Р. Психологическое содержание личностного самоопределения / М. Р. Гинзбург // Вопросы психологии. - 1994. — № 3. - С. 43-52.

8. Кон И.С. Психология ранней юности / И. С. Кон. - М. : Просвещение, 1989. - 256 с.

9. Ляхова А. М. Психологические составляющие жизненной стратегии личности / А. М. Ляхова // Вестник КемГУ. — 2010. — №3 (43). - С. 83-90.

10. Максименко С. Д. Генеза здійснення особистості / С. Д. Максименко. - К. : ТОВ «КММ», 2006. - 240c.

11. Петровский А. В. Психология в России: ХХ век / А. В. Петровский. — М. : Изд-во УРАО, 2000. - $312 \mathrm{c}$.

12. Резник Т. Е. Жизненные стратегии личности / Т. Е. Резник, Ю. М. Резник // Социологические исследования. - 1997. - №5. - С. 100-111.

13. Роменець В. А. Історія психології ХХ століття / В. А. Роменець. - К. : Либідь, 2003. $990 \mathrm{c.}$

14. Рубинштейн С. Л. Проблемы общей психологии / С. Л. Рубинштейн. - М. : Педагогика, 1973. - $423 \mathrm{c}$.

15. Титаренко Т. М. Життєвий світ особистості: у межах і за межами буденності / Т. М. Титаренко. — К. : Либідь, 2003. — 376 с. 
16. Фромм Э. Иметь или быть / Э. Фромм // пер. с нем. Э. Телятниковой. - Москва : АСТ, 2007. - $314 \mathrm{c}$.

17. Buhler Ch. Theoretical Observations about Life's Basic Tendencies / Ch. Buhler // American Journal of Psychotherapy - 1959. - Vol. 13. - №3. - P. 561-581.

18. Buhler Ch. Basic tendencies of human life / Ch. Buhler, F. Massarik // The Course of human life: a study of goals in the humanistic perspective / [ed. by Ch. Buhler, F. Massarik]. - N. Y. : Springer, 1968. - P. 92-102.

Аннотация. В статье представлены результаты исследования проблемы проектирования жизненного пути личности. Проанализированы основные подходы ученых к изучению содержания, структуры, механизмов проектирования жизненного пути личности, в том числе в условиях современного общества.

Ключевые слова: проектирование жизненного пути, личность, смысл жизни, жизненные цели, жизненные планы, самоопределение, самоосуществление, современное общество.

Abstract. The results of personality life way designing problem's elaboration are considered at the article. Main approaches of scientists to research of content, structure, devices of personality life way designing, formation of this personality phenomena at modern society are analyzed.

Keywords: life way's projecting, personality, sense of life, life purposes, life plans, self-determination, self-actualization, modern society. 